\title{
ЭВОЛЮЦИЯ ВНЕШНЕПОЛИТИЧЕСКИХ ПРИОРИТЕТОВ ГОСУДАРСТВ БАЛТИИ В ПЕРВОЕ ДЕСЯТИЛЕТИЕ ПОСЛЕ ИХ ВСТУПЛЕНИЯ В НАТО И ЕС (2004 - 2014 ГГ.)
}

\author{
А. А. ВОЛОДЬКИН \\ Институт истории НАН Беларуси \\ Минск, Республика Беларусь
}

В статье рассматривается развитие приоритетных направлений внешней политики трех государств Балтии (Литвы, Латвии и Эстонии) в период от их вступления в ЕС и НАТО весной 2004 г. до изменения политической ситуации в Европе в связи с началом международного кризиса вокруг Украины весной 2014 г. На основании широкого круга документальных источников и литературы по теме исследования автор выделил следующие главные направления внешней политики государств Балтии в данный период: 1) углубление интеграции в ЕС и НАТО и поиск ими собственной политической ниши в этих структурах, связанный с решением ряда специфических проблем, стоявших перед этими странами; 2) активизация отношений с постсоветскими государствами Восточной Европы (включая Беларусь), в основе которой лежали преимущественно ценностные подходы (а в случае Литвы - также и геополитический); 3 ) поддержание тесного партнерства с США, как главным гарантом их безопасности; 4) использование новых возможностей членства в ЕС и НАТО для решения проблем в отношениях с Россией. В заключении статьи представлены авторские выводы о динамике и основных тенденциях развития этих внешнеполитических приоритетов.

Ключевые слова: государства Балтии; Литва; Латвия; Эстония; внешняя политика; НАТО; ЕС; Восточное партнерство.

Образец цитирования: Володькин $A$. А. Эволюция внешнеполитических приоритетов государств Балтии в первое десятилетие после их вступления в НАТО и ЕС (2004 - 2014 гг.) // Актуальные проблемы международных отношений и глобального развития : сб. науч. статей. Минск, 2020. Вып. 8. С. 9-26. https://doi.org/10.33581/2311-9470-2020-8-9-26

Введение. После вступления стран Балтии в НАТО и ЕС весной 2004 г. и достижения ими двух важнейших стратегических целей внешней политики - перед ними встала проблема переоценки сло- 
жившейся системы внешнеполитических приоритетов в целях поиска собственной роли в европейской политике с учетом своего нового международного статуса. Прежние идеалистические представления о членстве в ЕС и НАТО, как панацее от всех бед, постепенно сменяются пониманием того, что отстаивать свои интересы в коллективных структурах очень непросто - особенно, таким малым странам, как Эстония, Латвия и Литва, и, что придется приложить серьезные усилия чтобы их голоса были услышаны, а интересы учтены.

В условиях ограниченности собственных ресурсов логичным ответом на этот вызов становится поиск каждым из трех государств своей политической специализации в европейских и евроатлантических структурах, которая позволила бы ему выделиться в определенной сфере и заработать авторитет в качестве важного звена европейской политики. При этом, выбор такой специализации был обусловлен как конкретными проблемами, с которыми сталкивались страны Балтии в этот период, так и теми внешнеполитическими ресурсами, которые уже имелись в их распоряжении. К числу таких ресурсов следует отнести, во-первых, особо тесные отношения с США, которые, с одной стороны, делали их проводниками американских интересов в Европе, а, с другой - позволяли рассчитывать на американскую поддержку при лоббировании своих интересов в коллективных структурах Запада. Во-вторых, соседство с Россией и ее особые интересы в отношении стран Балтии, для воздействия на которые Литва, Латвия и Эстония рассчитывали использовать коллективные механизмы ЕС и НАТО. В-третьих, период пребывания в составе СССР, который ранее рассматривался в этих трех государствах исключительно в качестве пассива, препятствующего их скорейшей интеграции в западное сообщество, в новых условиях становится актуальным политическим активом, который позволяет им претендовать на роль главных экспертов по постсоветским странам и проводников в эти страны западных моделей развития и политического влияния.

Актуальность темы исследования обусловлена следующим:

- государства Балтии являются непосредственными соседями Беларуси и без изучения исторических тенденций развития их внешнеполитических приоритетов невозможно формирование эффективной внешней политики нашей страны и устойчивых отношений с соседями; 
- поскольку страны Балтии, как и Беларусь, являются небольшими государствами, расположенными между такими крупными центрами силы, как коллективный Запад и Россия, их опыт представляет интерес с точки зрения стратегий реализации малыми странами своих интересов в процессе взаимодействия с более сильными государствами и интеграционными структурами.

Методология исследования. Объектом исследования в данной работе выступает внешняя политика трех государств Балтии - Литвы, Латвии и Эстонии. Предметом - эволюция ее приоритетных векторов на протяжении первого десятилетия после вступления этих стран в НАТО и ЕС. Нижней хронологической границей исследования является весна 2004 г., когда они стали полноправными членами этих двух объединений. В качестве верхней хронологической границы выступает начало нового долгосрочного обострения отношений между Россией и коллективным Западом в результате международного кризиса вокруг Украины весной 2004 г. Поскольку страны Балтии стремились играть активную роль в отношениях между Западом и Россией и прилагали существенные усилия для сближения Украины с EC, эти события стали определенным рубежом в развитии их внешней политики.

Целью исследования является выявление основных тенденций развития приоритетных векторов внешней политики государств Балтии в 2004-2014 гг. Для этого были поставлены задачи проанализировать следующие основные направления их внешней политики на данном историческом этапе:

1) углубление интеграции в ЕС и НАТО и поиск собственной политической ниши в этих структурах;

2) активизация отношений с постсоветскими государствами Восточной Европы;

3) поддержание тесного партнерства с США;

4) использование новых возможностей для решения проблем в отношениях с Россией.

Обзор источников и литературы по теме. Важными источниками исследования послужили официальные документы государств Балтии: программы деятельности правительств, парламентские резолюции и соглашения политических партий о целях и принципах внешней политики. Также были использованы публикации СМИ и информационные материалы о политических контактах, размещен- 
ные на официальных сайтах министерств иностранных дел стран Балтии, России и США.

Среди авторов, анализировавших в своих публикациях различные аспекты внешней политики Литвы, Латвии и Эстонии на протяжении исследуемого периода, хотелось бы отметить, прежде всего, эстонских политологов А. Касекампа и В. Веэбеля $[1 ; 2]$, а также русскоязычного эстонского социолога И. Розенфельда [3]. Кроме того, были использованы работы российского социолога Р. Х. Симоняна, рассмотревшего влияние на внутреннюю и внешнюю политику государств Балтии международного экономического кризиса 2008-2010 гг. [4; 5] и историка В.В. Воротникова, рассмотревшего вопросы взаимодействия стран Балтии с НАТО на протяжении исследуемого периода [6] и формирование концептуальных приоритетов их внешней политики в 2004-2012 гг. ${ }^{1}$

Результаты исследования. На момент своего вступления в ЕС страны Балтии были склонны примкнуть к лагерю евроскептиков во главе с Великобританией, выступающему против усиления полномочий европейских наднациональных структур, особенно в политической и военной сферах, где те могут стать конкурентами НАТО. Но уже в первые месяцы своего членства они пересмотрели прежние подходы. Их руководство быстро осознало, что Еврокомиссия является основным защитником интересов небольших членов ЕС перед лицом более сильных партнеров. Поэтому они никогда не поддерживали инициативы, направленные на ослабление полномочий Еврокомиссии. При этом по вопросу о принятии европейского Конституционного договора между тремя странами наметились различия подходов: если Латвия и Эстония заняли выжидательную позицию, то Литва стала первой страной ЕС, ратифицировавшей этот документ еще в 2004 г.

Подписание в 2005 г. вопреки интересам государств Балтии соглашения о строительстве трубопровода «Северный поток» также заставило их изменить свою политику в сторону большей поддержки углубления европейской интеграции. Они стали выступать за укрепление ОВПБ ЕС, особенно на российском направлении, и формирование общей европейской политики в энергетической сфере. Нако-

\footnotetext{
${ }^{1}$ Воротников В. В. Концепции и приоритеты внешней политики Латвии, Литвы и Эстонии в 2004-2012 гг. / диссертация на соискание ученой степени кандидата исторических наук по специальности: 07.00.03 - Всеобщая история (новая и новейшая). М., 2014. 381 с.
} 
нец, быстрый экономический рост и улучшение уровня жизни в первые годы после вступления способствовали росту популярности ЕС и поддержки европейской интеграции у населения Литвы, Латвии и Эстонии. Как отмечает А. Касекамп, усилилась поддержка даже такого направления европейской интеграции, как ЕПБО, ранее вызывавшего множество опасений [2, с. 12].

Поэтому начиная с 2006-2007 гг. страны Балтии перешли к всесторонней поддержке развития европейской интеграции, причем не только вглубь, но и вширь. Все три государства последовательно поддерживают идею дальнейшего расширения ЕС и принятия в него новых членов. Особую поддержку они оказывают кандидатуре Турции и приданию официального статуса кандидата на вступление Украине. В первом случае, по мнению А. Касекампа, речь идет о «благодарности за поддержку», которую Турция оказала странам Балтии при решении вопроса об их приеме в НАТО [2, с. 12]. Во втором - об активизации их внешней политики в отношении новых восточных соседей ЕС. Следует также отметить, что страны Балтии настороженно относились к принципу разноскоростной интеграции, опасаясь оказаться на обочине интегрирующейся Европы. Поэтому они без особых дебатов поддержали заключение Лиссабонского договора ЕС.

Поскольку вес государств Балтии в европейской политике не настолько велик, чтобы пытаться оказывать влияние на все ее направления, постепенно стала формироваться специализация Литвы, Латвии и Эстонии в Евросоюзе. Так, для Литвы бесспорным приоритетом в ЕС, как и в НАТО, становится обеспечение энергетической безопасности путем разработки соответствующей стратегии на уровне Евросоюза, ограничивающей возможности нефтегазовых монополий (прежде всего российских) устанавливать контроль над энергораспределительными сетями европейских стран, а также за счет использования европейских бюджетных фондов для строительных работ по соединению энергетической инфраструктуры стран Балтии с инфраструктурой государств Центральной и Западной Европы. Для Эстонии приоритетными направлениями стали постройка железнодорожной магистрали "Rail Baltic", которая должна связать Таллинн и Варшаву, а также формирование единого цифрового рынка ЕС и укрепление кибербезопасности в Европе [1, с. 29]. 
Такая же специализация государств Балтии проявилась и в рамках НАТО. Вскоре после масштабных кибератак на правительственные серверы и информационные системы Эстонии со стороны зарубежных хакеров в 2007 г. (которые эстонское правительство связывало с недружественными действиями России в ответ на перенос в Таллинне памятника «бронзового солдата»), эта страна объявила своим национальным приоритетом развитие защиты от кибертерроризма. И уже в следующем 2008 г. там был открыт Центр передового опыта НАТО в области кибербезопасности. В Литве, для которой после закрытия по требованию ЕС в 2009 г. Игналинской АЭС и конфликта с российским «Газпромом» из-за перепродажи нефтеперерабатывающего предприятия в г. Мажейкяй польским инвесторам особое значение приобрела проблема обеспечения устойчивости энергетической системы страны, в 2012 г. был открыт Центр передового опыта НАТО по энергетической безопасности.

Дольше всех со своей специализацией определялась Латвия. По мнению генерального секретаря НАТО А. Ф. Расмуссена, она преуспела в обеспечении коммуникаций для сил Альянса в Афганистане. В силу своего важного стратегического положения и более развитой, чем у соседей транзитной инфраструктуры, эта страна заняла важное место в формировании т.н. Северной распределительной системы транспортно-логистической сети поддержки военной операции НАТО в Афганистане. Поэтому в сентябре 2014 г. в Риге начал работу Центр передового опыта НАТО в сфере стратегических коммуникаций ${ }^{2}$.

Если говорить о роли НАТО в политике Литвы, Латвии и Эстонии в целом, следует отметить, что во всех без исключения стратегических документах этих стран в области национальной безопасности подчеркивалась роль Альянса как ее главного гаранта. Поэтому их основные опасения были связаны с вероятным ослаблением «евроатлантической солидарности», разногласиями внутри НАТО, которые могут ослабить его силы и возможности выполнять свои функции. При этом, в отличие от «старых» членов Альянса, для которых эта организация все больше приобретала значение политического, а не военного союза, государства Балтии продолжали настаивать на раз-

\footnotetext{
${ }^{2}$ Газета: будущий центр НАТО в Латвии заинтересовал иностранных шпионов // Новостной портал DELFI [Электронный ресурс]. 2014. URL : http://rus.delf.lv/news/daily/politics/gazetabuduschij-centr-nato-v-latvii-zainteresoval-inostrannyh-shpionov.d?id=43788288 (accessed 04.06.2020).
} 
витии военной составляющей НАТО и его способности выполнять свои обязательства по коллективной обороне в рамках статьи 5 Североатлантического договора. Поэтому они показательно участвовали почти во всех его военных операциях и регулярно проводили на своей территории совместные военные учения блока. Также, с момента своего приема в НАТО государства Балтии поднимали перед руководством Альянса вопрос о принятии стратегических планов их обороны. Однако, большинство европейских членов НАТО были против этого, поскольку они стремились убедить Россию, что прием стран Балтии в Альянс был чисто политическим ответом на их упорное стремление интегрироваться в Западное сообщество и не имеет никакой антироссийской направленности. Но российско-грузинский военный конфликт августа 2008 г. и поддержка позиции государств Балтии со стороны США в итоге склонили чашу весов в пользу разработки такого плана. Как писала британская газета "Guardian" со ссылкой на материалы портала Wiki Leaks, в обстановке строгой секретности на саммите НАТО в Лиссабоне в январе 2010 г. было принято решение распространить действие стратегического плана обороны для Польши “Eagle - Guardian” («Орел - защитник») также и на страны Балтии ${ }^{3}$.

Столь осторожная и нерешительная политика НАТО в этом вопросе вызвала разочарование у политических элит государств Балтии и заставило их пересмотреть свое отношение к трехстороннему военному сотрудничеству. Как отмечает в своей статье эстонский дипломат и сотрудник министерства обороны, М. Колга, проекты трехстороннего военного сотрудничества государств Балтии (БАЛТБАТ, БАЛТРОН, БАЛТДЕФКОЛ, БАЛТНЕТ и др.) были образованы на протяжении 1990-х гг., прежде всего, с целью продемонстрировать руководству НАТО их способность к международному взаимодействию в военной сфере и отработке на практике натовских стандартов, а также готовность не только «потреблять» коллективную безопасность, но и вносить свой посильный вклад в ее укрепление, чтобы ускорить тем самым свой прием в Альянс. Но уже накануне приема в НАТО эти проекты стали сворачивать - даже самый первый и самый известный из них, БАЛТБАТ, был распущен в 2003 г. [7, с.

\footnotetext{
3 WikiLeaks cables reveal secret NATO plans to defend Baltics from Russia // The Guardian. 06.12.2010 [Electronic resource]. 2010. URL : http://www.theguardian.com/world/2010/ dec/06/wikileaks-cables-nato-russia-baltics (accessed : 11.09.2014).
} 
134-135]. Политические элиты стран Балтии больше не видели в них смысла, поскольку теперь, по их мнению, безопасность трех государств будет обеспечиваться военным сотрудничеством всего НАТО и поддержание особых региональных структур рассматривалось, как неоправданная трата средств. Однако, видя нежелание Альянса серьезно укреплять их систему обороны, они вновь пересмотрели свой подход и в 2010 г. сводный Балтийский батальон был восстановлен.

В этот период меняется политика государств Балтии и в отношении постсоветских стран Восточной Европы. Особенно разительно это изменение было заметно в случае Литвы. В начале 1990-х гг. эта страна категорически отвергала любые варианты участия в политических объединениях с постсоветскими странами (даже если в них не предполагалось членство России - как, например, в проекте Балтийско-Черноморского Союза), а 8 июня 1992 г. приняла особый Конституционный акт, который объявлял любое вовлечение Литвы в «постсоветские восточные союзы» угрозой национальной безопасности. Поэтому, вплоть до вступления в НАТО и ЕС Литва, как и остальные страны Балтии, поддерживала отношения с постсоветскими государствами преимущественно в торгово-экономической сфере на двухсторонней основе. Но уже в 2004 г. принимаются программностратегические документы, которые фиксируют иные отношения к этим странам. Так, в резолюции Сейма Литвы от 1 мая 2004 г. «О направлениях внешней политики Литвы, после получения полноправного членства в ЕС и НАТО» среди приоритетов упоминались: распространение демократических ценностей, развитие сотрудничества с государствами восточного пограничья ЕС, вовлечение их в инициативу европейского соседства ${ }^{4}$. В выступлении временно исполнявшего обязанности президента страны А. Паулаускаса «Новая внешняя политика Литвы» в Вильнюсском университете 24 мая 2004 г. также говорилось о развитии отношений с Беларусью и Украиной в контексте поддержки демократических преобразований в этих странах и их сближения с ЕС. Поддержка демократических ценностей, а также европейских и евроатлантических устремлений в постсоветских странах Восточной Европы регулярно появлялась в списке

\footnotetext{
${ }^{4}$ Rezoliucija dèl Lietuvos Respublikos uţsienio politikos krypčių lietuvai tapus visateise NATO nare ir Europos Sajungos nare: Lietuvos Respublikos Seimas, 01.05.2004 // Teises aktų registras [Elrctronic resource]. 2004. URL : https://www.e-tar.lt/portal/en/legalAct/TAR.FE0A5A477336 (accessed : 21.05.2020).
} 
внешнеполитических приоритетов в программах правительств Литвы начиная с 2004 г. ${ }^{5}$ и в соглашениях политических партий Литвы «О целях и задачах внешней политики государства» ${ }^{6}$. Кроме того, в межпартийном соглашении на 2004-2008 гг., говорилось о стремлении сделать Литву региональным лидером и связующим звеном между форматами регионального сотрудничества в Северной, Центральной и Восточной Европе.

Началом практической реализации этого курса можно назвать участие литовского президента В. Адамкуса в качестве посредника в ноябре - декабре 2004 г. в переговорах между сторонами в ходе украинской «оранжевой революции». В следующем 2005 г. Литва, наряду с остальными странами Балтии, стала соучредителем Сообщества демократического выбора, в которое также вошли Украина, Молдова, Грузия, Румыния, Македония и Словения. Одним из наиболее значимых событий в формировании этого межгосударственного объединения стала конференция стран Балтийского и Черноморского регионов в Вильнюсе 4 мая 2006 г., на которой выступил вице - президент США Д. Чейни.

Таким образом, в основе политики в отношении постсоветских стран Восточной Европы лежал принцип продвижения европейских демократических ценностей. Впрочем, с началом реализации программы ЕС «Восточное партнерство» во внешней политике Литвы в Восточной Европе стало появляться и геополитическое измерение. Выражалось оно в стремлении обеспечить скорейшее сближение стран этого региона с EC, невзирая на их реальное продвижение в области построения работающих демократических институтов. Так, в

\footnotetext{
${ }^{5}$ Lietuvos Respublikos Vyriausybės 2004-2008 metu programa : 14.12.2004, Nr. X-43 // Lietuvos Respublikos Vyriausybė [Elrctronic resource]. 2004. URL : http://lrv.lt/uploads/main/documents/ files/Apie_vyriausybe/Ankstesnes_vyriausybes/Po_1990_metu/po_1990_13_programa.pdf (accessed : 23.05.2020); Lietuvos Respublikos Vyriausybès 2006-2008 metu programa : 18.07.2006, Nr. X-767 // Lietuvos Respublikos Vyriausybė [Elrctronic resource]. 2006. URL : http://lrv.lt/uploads/main/documents/files/Apie_vyriausybe/Ankstesnes_vyriausybes/Po_1990_metu /14_programa.pdf (accessed : 23.05.2020).

${ }^{6}$ Politinių partijų susitarimas dèl pagrindinių valstybès užsienio politikos tikslų ir uždavinių 20042008 metais: 05.10.2004// Lietuvos Respublikos Seimas [Elrctronic resource]. 2004. URL : https://www3.lrs.lt\%2Fdocs2\%2FQIYFTVQL.DOC\&h=AT3xlxf2gJZhnu2PXDq8B8C0426fTpX1Y4uUZuwdxMfvZCcQyUeb4cGOE36y1XG3RBcLx8kzi8Srhb7j8qIPhu2PbCsheJeZKjCbBdOfAU2j-ViqGSWveH3IEOlwim5cWO (accessed : 17.05.2020); Lietuvos politinių partijų susitarimas dèl 2008-2012 metų Lietuvos užsienio politikos principų, strateginių gairių ir tikslų : 28.10.2008 // Lietuvos Respublikos Seimas [Elrctronic resource]. 2008. URL : http://www3.lrs.lt/pls/inter/w5_show?p_r=5042\&p_d=80801\&p_k=1 (accessed : 17.05.2020).
} 
2009-2010 гг. по инициативе литовской стороны состоялся обмен визитами глав Литвы и Беларуси Д. Грибаускайте и А. Лукашенко, который вплоть до осени 2008 г. находился под санкциями ЕС и был персоной нон-грата в странах Евросоюза. Президент Литвы пыталась даже убедить ЕС признать переизбрание А. Лукашенко на очередной президентский срок, чтобы не допустить дальнейшего втягивания Беларуси в орбиту российского влияния, что свидетельствовало об отходе Литвы от чисто ценностного принципа.

Такой же подход проявился в политике Литвы в отношении Украины. Еще до начала литовского председательства в Совете ЕС, в феврале 2013 г. в Вильнюсе состоялась встреча президентов Литвы и Украины Д. Грибаускайте и В. Януковича, на которой стороны сосредоточились на условиях предлагаемого договора об ассоциации. Тогда же президент Литвы подчеркнула в беседе с В. Януковичем, что Украина должна сделать свой выбор между ассоциацией с ЕС и участием в инициированном Россией проекте евразийской интеграции. При этом Д. Грибаускайте активно лоббировала в европейских структурах заключение Договора об ассоциации Украины с ЕС невзирая на фактический отказ президента В.Януковича выполнять предварительные условия Брюсселя для заключения данного документа. В марте 2013 г. состоялись заседание Парламентской ассамблеи Литвы, Польши и Украины и 9-го заседание литовскоукраинской комиссии по сотрудничеству в вопросах европейской интеграции, после которых представители высшего политического руководства Литвы поспешили заявить о полной готовности Украины к подписанию соответствующего договора на грядущем саммите «Восточного партнерства» ${ }^{7}$. Однако украинское руководство никак не прокомментировало эти заявления, а за неделю до саммита приостановило подготовку к подписанию Договора об ассоциации.

Наряду с отказом Азербайджана от подписания аналогичного договора, это стало главным разочарованием Вильнюсского саммита, омрачившим итоги литовского председательства в ЕС. По мнению экспертов, впечатление от такого провала несколько скрасило лишь неожиданное потепление отношений с Беларусью, которая во время

\footnotetext{
${ }^{7}$ Носович А. «Восточное партнерство» и евроинтеграция: вместе или вместо? // Аналитический портал RuBaltic.Ru - 27.03.2013. [Электронный pecypc]. 2013. URL : http http://www.rubaltic.ru/article/ekonomika-i-biznes/vostochnoe-partnerstvo-i-evrointegratsiyavmeste-ili-vmesto/\#t20\%20c (accessed : 04.06.2020).
} 
саммита согласилась начать переговоры о заключении с ЕС соглашений об облегчении визового режима и реадмиссии ${ }^{8}$. А последовавший за этим международный кризис вокруг Украины привел к началу военного конфликта на Донбассе и кардинальному изменению ситуации в сфере международной безопасности в Европе, которое стало важнейшим рубежом в развитии внешней политики государств Балтии после их вступления в ЕС и НАТО.

Отношения государств Балтии с США достигли своей максимальной интенсивности в период президентства Дж. Буша-младшего (2001-2008 гг.). Всемерная и безусловная поддержка любых внешнеполитических действий США на международной арене сделала их в этот период ценными союзниками американского руководства в Европе. Это подтверждает целый ряд визитов с американской стороны на высшем и высоком уровнях.

Помимо уже упомянутого приезда в Вильнюс вице-президента США Д. Чейни в мае 2006 г., в 2005-2006 гг. страны Балтии дважды посетил американский президент Дж. Буш-младший и трижды - госсекретарь К. Райс. Так, 20-21 апреля 2005 г. она посетила Вильнюс для участия во встрече министров иностранных дел НАТО, а также заседаниях Совета НАТО-Россия и Комиссии НАТО-Украина ${ }^{9}$ А 6-7 мая того же года президент США Дж. Буш и госсекретарь К. Райс провели встречу с президентами государств Балтии в Риге в четырехстороннем формате ${ }^{10}$. При этом, заявив, что США никогда не оставят страны Балтии без защиты, Дж. Буш в то же время обратил внимание на необходимость соблюдения прав русскоязычных меньшинств в этих странах и улучшения отношений с Россией. 28-29 ноября 2006 г. Дж. Буш и К. Райс вновь прибыли в Ригу для участия в саммите НАТО. А накануне этого саммита, 27-28 ноября, они отдельно встре-

\footnotetext{
${ }^{8}$ Руководитель департамента политики представительства ЕС: Среди положительных итогов саммита в Вильнюсе - заявление Беларуси о готовности к началу переговоров в визовой сфере // БЕЛАПАН. 29.01.2014. [Электронный ресурс]. 2013. URL : http://belapan.by/archive/ 2014/01/29/media_eu_rb_es/ (accessed : 17.10.2019).

${ }^{9}$ Presidential and Secretaries Travels Abroad. Secretaries. Lithuania // U.S. Department of State Office of the Historian [Electronic resource]. URL : https://history.state.gov/departmenthistory/ travels/secretary/lithuania (accessed : 07.06.2020).

${ }^{10}$ Presidential and Secretaries Travels Abroad. Presidents. Latvia // U.S. Department of State Office of the Historian [Electronic resource]. URL : https://history.state.gov/departmenthistory/ travels/president/latvia (accessed : 07.06.2020).
} 
тились в Таллинне с президентом Эстонии Т. Х. Ильвесом ${ }^{11}$. Поскольку основная стратегическая цель государств Балтии - членство в НАТО была уже достигнута, эти встречи носили в большей степени характер политических консультаций и о каких-либо важных договоренностях, достигнутых на них, сведений нет. По всей видимости, главной задачей политики этих стран в отношении США на данном этапе было сохранение достигнутого высокого уровня партнерства и лоббирование в европейских структурах сохранения и укрепления трансатлантических связей, как залога жизнеспособности НАТО.

После прихода к власти в США администрации Б. Обамы происходит существенное изменение американских внешнеполитических приоритетов в сторону Азии, из-за чего значение государств Балтии, как союзников, для США объективно снижается. Поэтому в 2009 г. контакты между этими странами и США на высшем и высоком уровнях отсутствовали, а в 2010-2011 гг. поддерживались лишь в рамках многосторонних форматов (министерская встрече НАТО в Таллинне, министерские встречи Содружества демократического выбора и ОБСЕ в Вильнюсе, саммит НАТО в Чикаго).

Некоторая активизация в отношениях наметилась лишь в самом конце исследуемого периода. Так, 30 августа 2013 г. состоялся американо-балтийский саммит в Вашингтоне, в ходе которого президент США Б. Обама встретился с главами Латвии, Литвы и Эстонии А. Берзиньшем, Д. Грибаускайте и Т. Х. Ильвесом. А 7 сентября того же года госсекретарь США Дж. Керри в ходе встречи с министрами иностранных дел ЕС в Вильнюсе, отдельно встретился с президентом Литвы Д.Грибаускайте и министром иностранных дел Л. Линкявичюсом.

В первые годы после вступления стран Балтии в ЕС и НАТО наметились также определенные положительные сдвиги в их отношениях с Россией, что послужило поводом для оптимистичных экспертных оценок влияния вступления в эти организации на балтийскороссийские отношения. Так, в 2003 г. завершилась процедура ратификации российской думой договора о границе с Литвой, подписан-

\footnotetext{
${ }^{11}$ Presidential and Secretaries Travels Abroad. Presidents. Estonia // U.S. Department of State Office of the Historian [Electronic resource]. URL : https://history.state.gov/departmenthistory/ travels/president/estonia (accessed : 07.06.2020).
} 
ного еще в 1997 г. ${ }^{12}$ В 2005 г. был также подписан, но так и не вступил в силу договор о границе между Эстонией и Россией. Кроме того, в 2005 г. президент Латвии В. Вике-Фрейберга приняла приглашение президента В. Путина на празднование 60-летия Дня Победы в Москве, став, таким образом, первым из лидеров государств Балтии, принявшим участие в российских памятных мероприятиях, посвященных окончанию Второй мировой войны. А в 2006 г. была образована Совместная комиссия историков Литвы и России с целью разрешения спорных вопросов, связанных с историей российсколитовских отношений. Наконец, 27 марта 2007 г. в ходе визита в Россию премьер-министра Латвии А. Калвитиса был подписан и ратифицирован в достаточно сжатые сроки латвийско-российский договор о границе ${ }^{13}$.

Но уже весной 2007 г. в балтийско-российских отношениях начинаются так называемые «войны памяти», вызванные стремлением стран Балтии вновь актуализировать тему советской оккупации и использовать европейские структуры для распространения своего видения исторической роли СССР в судьбах народов Европы после Второй мировой войны.

Начало этим войнам положило решение эстонского правительства под руководством А. Ансипа о переносе из центра на окраину Таллинна памятника советским воинам, погибшим в боях за город против германского вермахта в 1944 г. (т.н. «Бронзовый солдат») [3]. Эта акция спровоцировала массовые протесты в самой Эстонии и вызвала широкий резонанс в России.

Вскоре за этими событиями последовали массовые атаки зарубежных хакеров на информационные ресурсы государственных органов Эстонии. Руководство страны обвинило в этом Россию. И даже встреча президента Эстонии Т. Х. Ильвеса 28 июня 2008 г. с президентом России В.В.Путиным в ходе V Всемирного конгресса финно-

\footnotetext{
12 Политические контакты // Посольство Российской Федерации в Литовской Республике [Электронный ресурc]. URL : http://www.lithuania.mid.ru/doc/polit_kontakt2011.htm (accessed : 18.03.2014).

13 Отношения России и Латвии // Министерство иностранных дел Российской Федерации [Электронный pecypc]. URL : http://www.mid.ru/ns-reuro.nsf/348bd0da1d5a7185432569e 700419c7a/f6c78dadee6ef35143256db1004ee8ff? OpenDocument (accessed : 18.03.2014).
} 
угорских народов в Ханты-Мансийске не привнесла в отношения двух стран положительную динамику ${ }^{14}$.

В 2008 г. ухудшение балтийско-российских отношений продолжилось в связи с тем, что Литва, Латвия и Эстония также, как Польша и Украина, открыто осудили военные действия России против Грузии в августе 2008 г. А 12 августа президенты всех этих пяти стран нанесли совместный визит в Тбилиси, чтобы выразить Грузии свою полную поддержку. Но своего апогея «войны памяти» достигли в 2009 г., когда сначала 2 апреля Европарламент принял инициированную государствами Балтии и странами ЦВЕ резолюцию о провозглашении 23 августа Европейским днем памяти жертв сталинизма и фашизма. А 3 июля того же года Парламентская Ассамблея ОБСЕ приняла выдвинутую все теми же странами резолюцию «О воссоединении разделенной Европы: защита прав человека и гражданских свобод в XXI веке в регионе ОБСЕ», в которой нацистский и коммунистический режимы провозглашались одинаково преступными и ответственными за развязывание Второй мировой войны. В этом же году прекратила свою деятельность Совместная комиссия историков Литвы и России.

В следующие два года под влиянием последствий мирового экономического кризиса и некоторого ослабления позиций правых партий, правление которых многие избиратели связывали с падением уровня жизни и непопулярными антикризисными мерами, идеологическая составляющая политики стран Балтии в отношении России заметно ослабевает, уступая место прагматичным экономическим интересам. Во внешней политике проявлением этой тенденции стала кратковременная активизация политических контактов с Россией на высшем уровне. Так, в 2010 г. президенты Латвии В. Затлерс и Эстонии Т. Х. Ильвес, приняли участие в праздновании 65-й годовщины Дня Победы в Москве и встретились с президентом России Д. Медведевым. Отказавшаяся примкнуть к ним президент Литвы Д. Грибаускаете, тем не менее, встретилась 10 февраля 2010 г. с занимавшим на тот момент пост главы российского правительства В. Путиным на саммите действий по Балтийскому морю в Хельсинки. В самом конце года, 19-21 декабря состоялся официальный визит в

${ }^{14}$ Relations between Estonia and Russia // Ministry of Foreign Affairs of the Republic of Estonia [Electronic resource]. URL : https://vm.ee/en/countries/russia?display=relations (accessed : 08.11.2017). 
Россию президента Латвии В. Затлерса, в ходе которого был подписан целый ряд двухсторонних соглашений, а также принято решение о создании Совместной комиссии историков Латвии и России ${ }^{15}$. А 18 февраля 2012 г. в Латвии даже состоялся референдум по вопросу о придании русскому языку статуса второго государственного.

Все эти события вызвали у российских экспертов и исследователей некоторую эйфорию, выражавшуюся в устойчиво повторявшихся прогнозах скорого и кардинального пересмотра внешнеполитических приоритетов государств Балтии в сторону сближения с Россией [4-6]. Однако, до 2014 г. эти прогнозы так и не осуществились. А последовавший затем международный кризис вокруг Украины и введение ЕС и Россией взаимных экономических санкций друг против друга окончательно похоронили перспективы скорой нормализации балтийскороссийских отношений и вновь сделали тему «российской угрозы» одним из самых актуальных вопросов в политическом дискурсе Литвы, Латвии и Эстонии.

Заключение. Вступление Литвы, Латвии и Эстонии весной 2004 г. в НАТО и ЕС стало важнейшим событием в истории балтийских государств с момента восстановления их независимости. Это обусловило серьезную переоценку внешнеполитических задач и приоритетов стран Балтии и положило начало расхождения их внешнеполитических стратегий. Латвия и Эстония, фактически, перестали проводить активную внешнюю политику, сосредоточившись на дальнейшей экономической и политической интеграции в рамках ЕС и НАТО и, в целом, ограничились поддержкой общей внешней политики этих структур. Литва же, напротив, обозначает свои претензии на региональное лидерство - расширяет контакты с постсоветскими странами Восточной Европы (включая Беларусь) и стремится укрепить свой вес в международной политике, активно участвуя в реализации Европейской политики соседства и программы ЕС «Восточное партнерство».

В начале исследуемого периода также наблюдалась активизация контактов государств Балтии с США и Россией. В случае балтийскоамериканских отношений это было связано с важным значением Литвы, Латвии и Эстонии для администрации Дж. Буша-младшего в ка-

15 Отношения России и Латвии // Министерство иностранных дел Российской Федерации [Электронный pecypc]. URL : http://www.mid.ru/ns-reuro.nsf/348bd0da1d5a71854325 69e700419c7a/f6c78dadee6ef35143256db1004ee8ff? OpenDocument (accessed : 18.03.2014). 
честве стратегических союзников США в Европе, а также стремлением самих этих стран сохранить достигнутый высокий уровень отношений с Вашингтоном. Также страны Балтии надеялись, что вступление в НАТО и ЕС автоматически снимет основные противоречия в балтийско-российских отношениях, что подкреплялось существенным прогрессом в заключении с Россией договоров о государственных границах. Однако, уже в 2007 - 2009 гг. на обоих этих направлениях начинается спад. Ухудшение балтийско-российских отношений началось с «войн памяти», в ходе которых Литва, Латвия и Эстония стремились, заручившись поддержкой европейских структур, вновь поднять вопрос ответственности за советскую оккупацию, а также бурной реакцией балтийских стран на военный конфликт между Россией и Грузией в августе 2008 г. Что касается снижения интенсивности политических контактов с США, оно было связано не с действиями государств Балтии, а с изменением внешнеполитических приоритетов новой американской администрации Б. Обамы в сторону Азии.

Международный кризис вокруг Украины, который разразился весной 2014 г., вызвал не только резкое ухудшение отношений между Западом и Россией, но и, как следствие, усугубил ситуацию в сфере международной безопасности на востоке Европы. Хотя эти события и не оказали столь масштабного воздействия на внешнюю политику государств Балтии, как их вступление в ЕС и НАТО, они обусловили изменение тех внешнеполитических стратегий, которых они придерживались на протяжении всего предыдущего десятилетия. В частности, в их внешнеполитический дискурс вновь вернулись более характерные для 1990-х гг. модели секьюритизации и тема экзистенциальной «угрозы с Востока».

\section{Библиографические ссылки}

1. Kasekamp A. Baltic States and the EU : A Rocky Road from "Outside" towards the "Core" // The Baltic States in the EU : Yesterday, Today and Tomorrow / A. Grigas, A. Kasekamp etc. Notre Europe Jacques Delors Institute Studies \& Reports. July 2013. P. 16-32.

2. Kasekamp A., Veebel V. Overcoming doubts: The Baltic states and the European Security and Defence Policy // The Estonian Foreign Policy Yearbook 2007. Tallinn : Estonian Foreign Policy Institute (EVI), 2007. P. 9-32.

3. Розенфельд И. Эстония до и после «бронзовой ночи». Тарту-С-Пб. : «Крипта», 2009. $576 \mathrm{c}$.

4. Симонян P. X. Страны Балтии: от обретения независимости до экономического кризиса // Горизонты экономики. 2011. № 1. С. 33-43. 
5. Симонян P. X. Финансово-экономический кризис в странах Балтии: некоторые политические итоги // Власть. 2010. № 11. С. 44-49.

6. Воротников В. В. Страны Балтии в НАТО : итоги десятилетия // Вестник МГИМО Университета. 2014. № 6 (39). С. 9-17.

7. Kolga M. Quo vadis Baltic defence cooperation? // The Estonian Foreign Policy Yearbook 2006.

Tallinn : Estonian Foreign Policy Institute (EVI), 2006. P. 119-136.

Дата поступления статьи: 16.11.2020.

Автор: Володькин Андрей Александрович - кандидат исторических наук, доцент, старший научный сотрудник центра истории геополитики Института истории Национальной академии наук Беларуси (Минск), докторант кафедры международных отношений Белорусского государственного университета (Минск); e-mail: valodzkin@bsu.by.

DOI: $10.33581 / 2311-9470-2020-8-9-26$

\title{
EVOLUTION OF THE FOREIGN POLICY PRIORITIES OF THE BALTIC STATES DURING THE FIRST DECADE SINCE THEIR ACCESSION TO NATO AND THE EU (2004 - 2014)
}

\section{A. A. VALODZKIN}

Institute of History of the National Academy of Sciences of Belarus

Minsk, Republic of Belarus

\begin{abstract}
The article examines the development of the foreign policy priority directions of the three Baltic states (Lithuania, Latvia and Estonia) during the period from their accession to the EU and NATO in the spring of 2004 to the dramatic change in political situation in Europe in as a result of the outbreak of the international crisis around Ukraine in the spring of 2014. Based on a wide range of documentary sources and literature on the research topic, the author highlights the following main directions of the foreign policy of the Baltic states within the mentioned period: 1) deepening integration into the EU and NATO and search for their own political niche in these structures, linked to the solving of some specific problems that these countries faced; 2) activation of relations with the post-Soviet states of Eastern Europe (including Belarus), founded on the values-based approaches (in the case of Lithuania - on geopolitical as well); 3) maintaining a close partnership with the United States, as their main source of security guarantees; 4) use of the new opportunities of their EU and NATO membership to solve their problems in relations with Russia. The fi-
\end{abstract}


nal chapter of the article presents the author's conclusions on the dynamics and main trends in the development of these foreign policy priorities.

Key words: Baltic states; Lithuania; Latvia; Estonia; foreign policy; NATO; EU; Eastern Partnership.

For citations: Valodzkin, A. A. (2020). Evolution of the foreign policy priorities of the Baltic states during the first decade since their accession to NATO and the EU (2004 - 2014). In: Actual Problems of International Relations and Global Development: collection of scientific papers, Minsk, Vol. 8, p. 9-26. https://doi.org/10.33581/2311-9470-2020-8-9-26

\section{References}

1. Kasekamp, A. (2013). Baltic States and the EU: A Rocky Road from "Outside" towards the "Core". The Baltic States in the EU: Yesterday, Today and Tomorrow. A. Grigas, A. Kasekamp etc. Notre Europe Jacques Delors Institute Studies \& Reports. July, p. 16-32.

2. Kasekamp, A., Veebel V. (2007). Overcoming doubts: The Baltic states and the European Security and Defence Policy. The Estonian Foreign Policy Yearbook 2007. Tallinn, Estonian Foreign Policy Institute (EVI), p. 9-32.

3. Rozenfel'd, I. (2009). Estoniya do i posle "bronzovoi nochi" [Estonia before and after the "bronze night"]. Tartu-S-Pb. 576 p. (In Russ.).

4. Simonyan, R. Kh. (2011). Strany Baltii: ot obreteniya nezavisimosti do ekonomicheskogo krizisa [The Baltic states from obtaining independence to economic crisis]. Gorizonty ekonomiki, 2011,1, p. 33-43. (In Rus.).

5. Simonyan, R. Kh. (2010). Finansovo-ekonomicheskii krizis v stranakh Baltii: nekotorye politicheskie itogi [Financial and Economic Crisis in the Baltic States: Some Political Results]. Vlast', 2010, 11, p. 44-49. (In Russ.).

6. Vorotnikov, V. V. (2014). Strany Baltii v NATO: itogi desyatiletiya [The Baltic states in NATO: summarizing the decade]. Vestnik MGIMO Universiteta, 2014, 6 (39), pp. 9-17. (In Russ.). 7. Kolga, M. (2006). Quo vadis Baltic defence cooperation? The Estonian Foreign Policy Yearbook 2006. Tallinn: Estonian Foreign Policy Institute (EVI), 2006, p. 119-136.

Received: 16.11 .2020 .

About author: Andrei Valodzkin - PhD in history of international relations and foreign policy, associate professor, senior researcher at the Centre of the history of geopolitics, Institute of History of the National Academy of Sciences of Belarus (Minsk, Belarus), habilitation doctoral fellow of the International relations department of the Belarusian State University (Minsk, Belarus); e-mail: valodzkin@bsu.by. 